\title{
Analysis of Hassan's Tragedy in the Kite Runner from the Three-dimensional Ethical Perspective
}

\author{
Peng Yuan-yuan ${ }^{1}$ \\ ${ }^{1}$ Tourism Department of Leshan Vocational \& Technical College, China \\ Correspondence: Peng Yuan-yuan, Tourism Department of Leshan Vocational \& Technical College, Leshan, \\ Sichuan, China. Tel: 86-189-9060-2585. E-mail: 1902615046@qq.com
}

Received: May 5, 2018 Accepted: June 6, 2018 Online Published: June 8, 2018

doi: 10.5539/elt.v11n7p URL: http://doi.org/10.5539/elt.v11n7p57

\begin{abstract}
Hassan in The Kite Runner was brave, kind-hearted and loyal, but he still ended up with misery. From the three dimensional ethical perspective, Hassan's tragedy is not only greatly related to national and religious ethics, but also influenced by deformed family ethics. Thus it can be seen that national discrimination and religious hierarchy exert negative impact on morality of Afghans. It is through this novel that Hosseini aims to reveals his broad humanistic feelings and call for others' attention to Afghanistan as well.
\end{abstract}

Keywords: The Kite Runner, family ethics, national ethics, religious ethics

\section{Introduction}

The Kite Runner was written by Khaled Hosseini, an Afghan living in America. It is a novel about a heartbreaking story in Kabul, the capital city of Afghanistan. A 12-year-old boy named Amir was determined to win the competition and run for the last kite successfully, in order to win the approval of his father, one of the richest and most respected merchants in Kabul. His loyal friend Hassan, his half-brother, the son of his father's servant, and the best kite runner that Amir had ever seen, promised to help him. Hassan always helped Amir out of trouble. For him, a thousand times over. However, Hassan was raped by Assef on the way to catch the kite for Amir, Amir hided and kept silent. Amir felt grievous and guilty for his cowardice and he could not confront Hassan, using something contemptible to let Hassan and his father leave his home. Not long, a war broke out in Afghanistan, Amir and his father had to escape to America. He couldn't forgive what he had done to Hassan before. Once in a while, he got the truth that Hassan was the son of his father and the wife of Ali from his teacher, he returned his hometown, which was badly destroyed by the war. While, Hassan, his brother and he and his wife died, left their son Sohrab alone. Rahim requested him to rescue Sohrab. This time he fought for Sohrab and finally got Sohrab back and took him to America.

Chinese Professor Nie Zhenzhao pointed out, "To some extent, literature was originally created solely for ethical and moral purposes. It provides moral examples for human beings to understand society and life from an ethical perspective, moral guidance for material and spiritual life of human beings, and moral experience for human self-improvement." The Kite Runner is a great work full of moral enlightenment, in which the experience of the Afghan people described can give readers a strong resonance. The novel successfully reproduced an unique ethical picture of the the Afghanistan as well as the ordinary Afghans hard life situation for more than 30 years to the readers, and revealed those that lived at the bottom of society in Afghanistan suffering from the dual oppression of race and religion. Critics have explored the author's questioning of Afghanistan's traditional notions of national and religious hierarchy from the perspectives of theme research, prototype criticism and symbolism, and reflected on the Afghan war and Taliban rule. Nie also pointed out that, to analyse the ethical fate of Hassan's in literature ethics criticism method, it must be "returning to the scene of the history of ethics, standing at the time of the ethical stance on interpretation and interpretation of literary works, analysis works leading to social events and the factors affecting the ethical fate of the characters, with the ethical point of view and give explanations of events, characters, literature, insist on a realistic moral values described in the literature of moral phenomenon make value judgment."

This paper analyzes the influence of family ethics, national ethics and religious ethics on the tragic fate of Hassan from the perspective of three-dimensional ethics. Through this novel, the author not only questions and criticizes the traditional and rigid ethical concepts, but also reveals his own humanitarian ethics. 


\section{A Deformed Family Ethic Order}

Hassan, born with a cleft lip, was the son of Amir's father and the wife of his servant, and abandoned by his biological parents. His mother abandoned him and eloped with other man seven days after he was born for her own happiness, while his biological father chose to abandon him for his honor. Hassan spent his childhood in the absence of maternal love, he had not been able to experience his mother's thoughtfulness and caring like other children. More sadly, he had to endure the others' jeers and insults for his mother's scandal. On the face, hassan seemed to have never lost father's love, but in fact Ali was only the father in name, and Amir's father was Hassan's biological father. In the social context of the time, Amir's father could not acknowledge the fact that Hassan was his own son, because Hassan was born to the wife of his servant Ali. To the Pushtuns, this immoral sexual relationship was an unforgivable sin. To protect his own reputation, Amir's father's had to abandon Hassan. He was often bullied and ridiculed by people around him because he was at the bottom of the society, but Ali couldn't help it. Hassan would not have been bullied or humiliated if Ali had belonged to the upper class like Amir's father, or just a Pushtun. Unfortunately, Ali was also a Hazara at the bottom of society.

On the other hand, Hassan and Amir didn't know about the dysfunctional family relationship. As a result, Amir could not understand his father's love and atonement for Hassan, his father's indifference to him, which greatly aroused Amir's strong jealousy, especially when dad specially invited India cosmetic surgeon to sew cleft lip for Hassan, Amir even hope himself have the similar blemish so that he could also get his father's love. Thus it can be seen that Amir is eager for father's love. Moreover, in Amir father's eyes, Hassan was brave and strong-willed unyielding like the Pashtuns, while Amir liked writing poems and had a weak character, his father was full of dissatisfaction and indifference to Amir, he wanted to cultivate Amir to love sports, strong-willed unyielding character. This unwholesome father-son relationship was so painful for Amir's young mind that he regarded Hassan for his father-loving enemy. Therefore, he tried to get Hassan out of his house, Amir did not know that Hassan was his half-brother, and that his father was not just for his kindness, but for his guilt.

In fact, Hassan's tragedy was avoidable. If baba had dared to admit that Hassan was his own son, Hassan would have grown up under his father's umbrella. Firstly, Amir would not be unscrupulous and bully his half-brother. Secondly, Hassan would not be left in the war, even if he had been killed by the Taliban, who had not been discriminated against by the Hazara. Apparently, the estranged father-son relationship between Amir and baba led to Amir's jealousy of Hassan, eventually betraying Hassan, who was willing to sacrifice everything for him. And the invisible "father-son relationship" between baba and Hassan was the most direct cause of Amir's betrayal of Hassan, and the effect of this deformed family ethic on the fate of the characters.

\section{Ethnic and Ethical Order of Inequality}

"The kite runner" is a novel based on Afghanistan, which illustrated the social changes in Afghanistan in the last 30 years, while there was serious racial discrimination in Afghanistan. By writing the relationship between people in the novel, the author had also revealed the complex ethnic relations in Afghanistan, namely the relationship between the Pashtun ethnic group and the Hazara ethnic group. The Pashtuns were the main ethnic group in Afghanistan and had long dominated political, economic, religious and military affairs, from the upper echelons of society. The minority Hazara, however, were dominated by the people who belong to the lower class. In such an unequal ethnic ethical order, the Hazaras, as ethnic minorities, were destined to be discriminated against and persecuted by Pashtuns.

In his novel, Assef was the face of Afghan nationalism. In his eyes, Afghanistan had always been the Pushtuns, and they were the pure afghans. The Hazaras were aliens and should be cleared out of Afghanistan like garbage. In addition to Assef, the novel mentions the soldiers who humiliated Hassan or the passers-by, especially the teachers of Amir. Clearly, the Pashtuns' racial discrimination was deep-rooted and difficult to eradicate. The Hazaras were often brutally treated by Pashtuns, and they did not need a good reason to be killed. In particular, when the Taliban ruled Afghanistan, the more extreme national policies were introduced, and the idea of an unequal national hierarchy became more specific and more acute. This had brought greater misery to the Hazaras, and massacred Hazaras in 1998. In 2001, in retaliation for the long-insubordination of the Hazara clan, the Taliban indiscriminately massacred nearly a thousand Hazara members in the suppression of their armed rebellion.

Therefore, to see the social roots of Hassan's tragedy, as professor Nie Zhenzhao said, "the ethical factors that influence the fate of the characters should be analyzed in the social ethical position of the time. If it goes back to the context of Afghan ethics described in the novel, it is not difficult to interpret the ethical reasons for Hassan's tragedy." In the novel, Amir Hassan's attitude and way, also reflected the social attitude and form of Hassan, because "Amir domestic inequality is between nation inequality." the idea of racial discrimination was born, and 
it had already taken root in the hearts of Hassan and Amir. Grew up drinking milk of the same woman, living in the same place, because Hassan was a Hazara boy, though loyal to Amir, never be regarded as a friend, because there was a racist barriers between them. The sense of national superiority made him take it for granted that Hassan "would only be in the kitchen all his life, and he would dare to criticize me? This Hazara was illiterate. Apparently, Amir seemed to play with Hassan often, and sometimes even to soothe Hassan. In fact, he subconsciously placed Hassan at the bottom of the heap. On the face of it, Amir betrayed Hassan in order to win recognition and approval from his father. In fact, the idea of racial discrimination is the primary cause of Amir Hassan betrayal, and listen to the inner monologue Amir, "In order to win back my dad, maybe Hassan is must pay the price, is I must kill the lamb," because he "was just a Hazara, isn't it?".

Hassan didn't complain about Amir's treachery and framing, Hassan sacrificed himself to preserve narrow and selfish Amir because he was bounded by the class and social ethics, which made him willing to bear everything in their own ethics and class environment. As a result, Hassan had never shown any dissatisfaction with this unequal status, nor had he tried to change his fate. When Assef was raging against Hassan, he was willing to sacrifice himself to help Amir achieve his father's approval. Hassan was again persecuted by racial discrimination in order to take care of the yard and return to Kabul. They shot Hassan brutally for they thought the lower Hazaras like Hassan could not live in a house like the Amir's .

There was no doubt that this inequality of the ethical order of the nation is a social cause of the tragedy destiny Hassan. Hassan was a victim of Afghanistan's ethnic tensions. His experience was a microcosm of many afghans and the vicissitudes of Afghanistan's half-century. It can be said that his tragedy is the tragedy of the whole Hazara and the Afghan society.

\section{A Narrow Religious and Ethical Order}

In "the kite runner", in addition to ethnic relations, Hussein also showed readers the religious ties of the Afghan nation. There was a serious ethnic hierarchy in Afghanistan, so did the religious sects. To some extent, religion had not only played a leading role in the military, political and economic development of Afghanistan, but also had a significant impact on the establishment of the social ethic order in Afghanistan. In Afghanistan, the dominant Pashtuns were devout Sunnis, they claimed to be orthodox Islam, and ruled and dominated the political, economic and religious affairs of Afghanistan, while the Hazaras were also ruled. As Amir mother described the history books "Pushtun had persecuted Hazaras, killed the Hazaras hazard, and burned their home, sold their women, forced them to flee their homes. The book argued that the Pushtuns persecute the Hazaras, partly because the former were Sunni Muslims and the latter were Shia. When Amir showed his teacher with confusion, his teacher referred to the word Shia as if he were referring to a disease, and saw the persecution of people by a narrow religious ethic.

Hassan was a dominant figure in both ethnic and religious relations. Hassan himself, from the bottom of his heart, accepted the inherent inferior position, while Amir couldn't treat Hassan as a friend. Ethnic and religious ethics were heavy chains that held amir and hassan tightly. This subliminal religious hierarchy was also one of the social causes of the tragic fate of Hassan.

In "the kite runner", author Hosseini succeeded in portraying a narrow, selfish Amir, while also vividly portraying a brave Hassan. The author's real intention was not just to expose ethnic problems, religious relationship, but also to describe the current life situation of the ordinary Afghans, and made the readers know Afghanistan. Though Hassan smart, kind, brave and loyal, but still unable to escape the clutches of the traditional ethical order in Afghanistan, it served to show the traditional rigid ethical spirit of the Afghan people suppressed and distorted. There was no doubt that the novel Hassan's tragic fate was the consequences of ethnic and religious contradictions intensified, but also the tragedy of the social ethics, it was the Afghan society of traditional ethics order and spirit of the Afghan people thought suppression, caused Hassan's"tragedies.

\section{References}

Khaled, H. (2004). The Kite Runner. Bloomsbury Publishing PLC.

Lin, Q. Q. (2013). Analysis of Hassan's Tragedy in The Kite Runner. Journal of Hainan Radio \& TV University.

Nie, Z. Z. (2005). Criticism of Literary Ethics. Foreign literature research, 1, 8-11.

Zeng, W. Q. (2013). SHANG xiao-jin. The Kite Runner Character Relationship Implied in Afghanistan National Relations. Social sciences, 3, 259-269. 


\section{Copyrights}

Copyright for this article is retained by the author(s), with first publication rights granted to the journal.

This is an open-access article distributed under the terms and conditions of the Creative Commons Attribution license (http://creativecommons.org/licenses/by/4.0/). 